\title{
Modeling Waste Management Options for Greenhouse Gas Reduction
}

\author{
S. Thompson ${ }^{*}$ and S. Tanapat
}

Natural Resources Institute, University of Manitoba, 70 Dysart Rd, Winnipeg, Manitoba, R3T 2N2

\begin{abstract}
Solid waste management requires that new concerns regarding climate change be considered. The utility of the Scholl Canyon model to determine greenhouse gas generation for different waste management options at specific sites is explored in this paper looking at Brady Road Landfill in Winnipeg, Canada. Determination of the feasibility of methane recovery for Brady Road Landfill required three steps: 1) measuring landfill gas composition and site conditions; 2) inputting field data as constants, as well as accepted constants, into the Scholl Canyon model to determine gas generation under different waste management options such as different composting programs; and 3) comparing greenhouse gas production according to the Scholl Canyon model. Modeling results indicate that it is feasible to recover methane at Brady Road Landfill under different waste management scenarios that include a composting program that is highly successful in diverting waste. Estimates of gas generation at Brady Road Landfill show it is possible and lucrative to harvest landfill gas, with or without composting, which would significantly reduce greenhouse gas emissions.
\end{abstract}

Keywords: Climate change, landfill gas, methane, methane recovery, waste management

\section{Introduction}

Canada has the second highest methane emissions per capita from solid waste disposal on land among the numerous countries in the United Nations Framework Convention on Climate Change Parties (UNFCC, 2003). For the Kyoto protocol, Canada promised to reduce GHG emissions to $6 \%$ below 1990 levels between 2008 and 2012. However, rather than decreasing, methane emissions from Canadian landfills increased by $24.4 \%$ between 1990 and 2001 despite an increase in landfill gas capture and combustion of almost 33\% over the same period (Environment Canada, 2003). This increase surpassed the population growth of $12.2 \%$ amounting to an increase in emissions of $10 \%$ per Canadian (Environment Canada, 2003). Canada's high methane emissions per capita from solid waste disposal on land require that new strategies to reduce methane emissions be considered.

Landfill gas is basically made up of half methane and half carbon dioxide $\left(\mathrm{CO}_{2}\right)$, two potent greenhouse gases, as well as small amounts of hydrogen, oxygen, nitrogen, hydrogen sulphide and trace amounts of non-organic compounds and volatile organic compounds (Schumacher, 1983; Gardner et al., 1993). In Canada, methane emissions account for approximately $12.6 \%$ of Canada's $\mathrm{CO}_{2}$ equivalent $\left(\mathrm{eCO}_{2}\right)$ GHG emissions with almost one-quarter (24\%) arising from landfills (Canadian Electricity Association, 2002). Methane is typically generated during a 30 to 50 year period as waste undergoes anaerobic decomposition. Methane is the central concern for greenhouse gas emissions from landfills as it has 21 times the global warming potential of $\mathrm{CO}_{2}$ with a long

\footnotetext{
* Corresponding author: s_thompson@umanitoba.ca
}

lifespan of 150 years. Also, the $\mathrm{CO}_{2}$ produced from burning or aerobic decomposition of biomass, unlike methane, is deemed a sustainable cycle, as carbon in $\mathrm{CO}_{2}$ is sequestered when the biomass regenerates (Environment Canada, 2003).

Several waste management options are compared, in this paper, for methane emissions at Brady Road Landfill in Winnipeg, Manitoba by the Scholl Canyon model. Brady Road Landfill is the largest landfill in Canada that is unmanaged for greenhouse gases (Environment Canada, 1999). Brady Road Landfill is expected to generate substantial amounts of biogas based on: $57 \%$ of its waste stream being biowaste; its capacity to grow to 50 million metric tonnes from its present size of 5 million metric tonnes of waste; and an expected lifespan of $150+$ years (Canada Electricity Association, 2002). At present the Landfill is operated by the City of Winnipeg without composting (other than yard waste), without flaring of methane and without recapturing of methane gas for energy. This leaves options for composting food wastes and recovering methane for heating or electrical generation possible to reduce greenhouse gas generation. The methane recovery option is currently being studied by the City of Winnipeg. Even at its current size, rough estimates for electricity production from methane recovery at Brady Road Landfill are 6.7 megawatt hours (MWh) per year of electricity, while reducing 0.4 megatonnes of greenhouse gas emissions (Province of Manitoba, 2002).

This paper considers both landfill gas recovery, as well as the second option of implementing aggressive composting programs in tandem with methane recovery at Brady Road Landfill. The systematic recovery and utilization of landfill gas generated during anaerobic decomposition of municipal solid wastes both reduces GHG emissions and creates an 
alternative renewable source of energy to replace fossil fuel use (Smith et al., 2001; Pembina Institute, 2003). One tonne of household waste has a methane gas production potential of 180 to 250 cubic meters during the 30 to 50 year period that it takes waste to decompose. If the methane is recovered from one tonne of waste approximately 1000 kilowatt hours $(\mathrm{kWh})$ is produced, as one cubic metre of methane gas has an energy value of four to five kWh (Pembina Institute, 2003). In 2001, there were 42 landfill gas collection systems (Environment Canada, 2003) capturing about $280 \mathrm{Kt}$ of methane, including eight landfill gas-to-energy plants generating about $85 \mathrm{MWh}$ per year of electricity. Methane recovery of landfill gas represents one of the most cost effective means to reduce GHG emissions due to both fuel sales and credits from GHG reduction. Conestoga Rovers and Associates (1999) reported that the price of GHG reduction (aka GHG credits) is between $\$ 1.00$ and $\$ 2.00$ (CAD value based on 1999) per tonne of $\mathrm{eCO}_{2}$ reduced. In addition, the capture and use of landfill gas provides the ancillary benefits of limiting odours, controlling damage to vegetation, minimizing owner liability, reducing risk from explosions, fires and asphyxiation, and smog while providing a potential source of revenue and profit (Smith et al., 2001).

Despite its many benefits, methane recovery is essentially an "end of pipe" solution, which does not actively tackle the root cause of waste generation, unlike composting. Composting organic matter considers broader ecological issues such as resource-use efficiency, avoided ecological impacts, and improvements in soil stability, fertility and moisture-retaining properties (Smith et al., 2001). The GHG reduction from paper recycling and composting over landfilling depends on the efficiency with which the landfill is assumed to control landfill gas emissions and ranges from 50 to $280 \mathrm{~kg} \mathrm{eCO}$ of municipal solid waste (Smith et al., 2001). In addition, full-scale composting, such as the Cleanit Greenit Composting System in West Edmonton, has been proved to significantly reduce greenhouse gas emissions (CastroWunsch and Ng-Grondin, 2001). Under aerobic conditions, methane is not produced in composting operations, however, usually some anaerobic decomposition occurs due to the incomplete aeration of compost.

The state-of-the-art composting and landfill gas recovery facility in Edmonton, Alberta demonstrates the efficacy in multi-faceted environmental systems for waste management. Guelph in Ontario and Halifax in Nova Scotia are two other Canadian municipalities that effectively collect organic waste for composting with rates of diversion as high as 68\%, thereby reducing GHG at their source (Environment Canada, 2001). The Scholl Canyon model is applied to estimate the energy potential of Brady Road Landfill. This simple model is widely used in the landfill gas industry in Canada and the United States, particularly for landfills with greater than one million tonnes of waste in places, like the Brady Road Landfill (USEPA, 1996; Environment Canada, 2003). However, it has never been used as a management tool to compare different waste management options. This model is consistent with Environment Canada and the International Panel on Climate
Change (IPCC) protocols for calculating GHG emissions. The Scholl Canyon model assumes that after a lag time of negligible duration, during which anaerobic conditions are established and the microbial biomass are built up and stabilized, the gas production rate is at its peak (Schumacher, 1983). This model is an exponential decay model dependent on factors that affect biodegradation rates (e.g., age of waste, moisture content, etc.) used to estimate methane generation from landfills but has not been applied to compare waste management options. Gas generation is modelled over an extended period to better understand its magnitude and potential to double and triple rates of methane generation from landfills over time. By conducting monitoring in 2003-2004 at Brady Road Landfill the feasibility of methane recovery under different waste management options, based on site-specific factors, as shown in section 2, was determined.

\section{Methods}

Three steps were carried out to determine GHG generation under different waste management options, namely: 1) measuring landfill gas composition and Brady Road Landfill site conditions; 2) entering field data and accepted constants into the Scholl Canyon model; and 3) determining gas generation under different waste management options for composting.

\section{Step 1: Measuring Landfill Gas}

Measuring landfill gas required installing probes to test landfill gas production. On June $20^{\text {th }}$, 2003, five 10 metre by one-inch-diameter polyvinyl chloride (PVC) pipe sampling probes were installed to reach the bottom of the waste cells in Brady Road Landfill. The gas monitoring probes were installed at sites chosen for being: (1) the most active sites for gas generation; and (2) geographically distributed and representative of the landfill surface area. To capture methane the sample probe's end was perforated for the bottom two metres and capped at the top. Fifteen air samples were collected bi-weekly by plastic syringes, with triplicate samples for each of the five probes providing quality control for a year. Fifteen samples were averaged for each sampling date. Meteorological monitoring was also conducted to record temperature, moisture content, and barometric pressure throughout the sampling program.

Step 2: Applying field data into constants, as well as accepted constants, as inputs to Scholl Canyon Model

The Scholl Canyon Model is applied below to the Brady Road Landfill site to determine methane generation comparing site specific parameters in step 2 with accepted constants for the methane generation potential $\left(L_{0}\right)$ and the decay rate constant $(k)$ :

$d L / d t=k L_{o} \sum_{i=1}^{n} r_{i} e_{i}^{-k_{i} t_{i}}$

where $L$ is the amount of gas generated per unit weight of 
refuse $\left(\mathrm{m}^{3}\right.$ methane/tonne of waste or standard cubic feet per minute (SCFM)); $L_{0}$ is the methane generation potential $\left(\mathrm{m}^{3}\right.$ methane/tonne of waste); $n$ is the number of years considered from its opening in 1973 to 2050; $t_{i}$ is the time from placement year 1973 to 2050 (years); $k_{i}$ is the decay rate constant each year, which was estimated to be close to the average constant for Canada at $k=0.01$ (Environment Canada, 2001); $r_{i}$ is a ratio of the tonnage of all previous years accumulated to the landfill's maximum capacity of landfill. A fraction of total refuse $\left(r_{i}\right)$ was obtained from the amount of refuse deposited each year between 1973 and 2050 divided by the expected site capacity of 50 million tonnes (i.e. $\left.r_{(1973)} 30,000 / 50,000,000\right)$.

The methane generation potential $\left(L_{0}\right)$ and decay rate $(k)$ constants are applied to the model to estimate landfill gas potential, including both site specific data based on monitoring as well as accepted constants. The site specific mean value with standard deviation of $L_{0}=111 \pm 2.65$ cubic metres per tonne or $1.78 \pm 0.04$ is determined by the equation (IPCC, 1996):

$L_{o}=F \times M C F \times D O C \times D O C_{F} \times 16 / 12$

where $F$ is the fraction of $\mathrm{CH}_{4}$ in landfill gas $\left(56 \% \mathrm{CH}_{4}\right.$ measured in biogas); $M C F$ is the methane correction factor $(1=$ well managed landfill); $D O C$ is degradable organic carbon (fraction), which was $18.1 \%$ at Brady Road (City of Winnipeg, 2000); $D O C_{\mathrm{F}}$ is the fraction degradable organic carbon assimilated $(0.82)$ based on the equation: $D O C_{\mathrm{F}}=0.83-$ 0.028 LC (Tchobanoglous et al., 1993) using average volatile lignin content (LC) of $44.1 \%$ determined from the results of leachate sampling.

Step 3: Comparing Greenhouse Gas Production according to the Scholl Canyon model

The rates of greenhouse gas (landfill gas generation potential) are determined for different waste management strategies, including business-as-usual (zero diversion), 50\% diversion and 75\% diversion, until the year 2050.

\section{Results}

\section{Step 1: Gas Composition Results}

Triplicate gas samples taken from each of the five gas monitoring probe resulted in 15 samples being averaged for each sampling date. The sampling results showed that composition was consistent over a year as illustrated in Figure 1.

The mean average and standard deviation of gas chemical composition of methane and $\mathrm{CO}_{2}$ was $56.10 \pm 2.56 \%$ and $40.09 \pm 3.00 \%$, while the average values of nitrogen and oxygen were $1.66 \pm 1.24 \%$ and $0.73 \pm 0.45 \%$, respectively. Seasonal changes in atmospheric pressure and temperature are shown in Figure 2. That only minute concentrations of oxygen and nitrogen were found demonstrates that the sampling and testing process was uncontaminated by outside air.

The landfill gas temperature was relatively constant in comparison to the ambient temperature and atmospheric pressure, except briefly on March 20th, 2004 (day 236). This drop in landfill gas temperature is explained by spring snow-melt dropping the temperature $6^{\circ} \mathrm{C}$ in the waste cell for a short period of time.

Step 2: Applying field data into constants, as well as accepted constants, as inputs to Scholl Canyon Model

The site-specific constants are compared to three sets of constants from the US EPA (2001) as well as one set of constants from Environment Canada (Llevelton, 1991). These constants, shown in Table 1, show the variation possible due to constants.

Table 1. Input Parameters Used in Landfill Gas Model (USEPA, 2001; Llevelton, 1991)

\begin{tabular}{llll}
\hline Source & Lo $\left(\mathrm{ft}^{3} / \mathrm{lb}\right)$ & Lo $\left(\mathrm{m}^{3} /\right.$ tonne $)$ & $\mathrm{K}\left(\mathrm{year}^{-1}\right)$ \\
\hline Brady Road Site specific & 1.78 & 111 & 0.01 \\
\multicolumn{4}{l}{ US EPA default Values (US EPA, 2001) } \\
CAA & 2.72 & 170 & 0.05 \\
AP-42 (wet) & 1.6 & 100 & 0.04 \\
AP-42 (dry) & 1.6 & 100 & 0.02 \\
Environment Canada Default Values (Llevelton, 1991) \\
EC & 1.87 & 117 & 0.006 \\
\hline
\end{tabular}

Note: CAA = Clean Air Act (US EPA, 2001), AP-42 = Compilation of air pollution emission factors (US EPA 2001), EC = Environment Canada (Llevelton, 1991); Waste Tonnage (metric tonnes): 1997 (3,000 tonnes), 2000 (375,000 tonnes), 2025 (450,000), 2050 $(450,000)$

Step 3: Comparing Greenhouse Gas Production according to the Scholl Canyon model

Landfill gas generation rates could be as high as 2,100 to 5,800 SCFM (depending on constants applied) according to Figure 3, if no waste is diverted. Or as low as 1,200 to 2,900 in Figure 5, if $75 \%$ of waste is diverted. In Figures 4 and 5 the graphs clearly show that composting programs would cause a dramatic decrease in methane, to as much as one-quarter the business-as-usual rate.

\section{Step 4: Greenhouse Gas Emission Reduction}

Figure 6 demonstrates the estimated potential to reduce greenhouse gas emissions (2004-2050) under a businessas-usual scenario (zero diverted above current rate of diversion).

Emissions of greenhouse gas emissions (average $\mathrm{eCO}_{2}$ of 167,489 tonnes per year over the next 50 years) show the landfill produces a significant amounts of methane to the atmosphere, that is presently not recovered.

Step 5: Calorific Value and Landfill Gas Energy Potential

The goal of this section is to determine the amount of site-specific heating value and electricity potential available from the biosolid waste at Brady Road Landfill. The calorific value or heating value is normally determined by the percent 


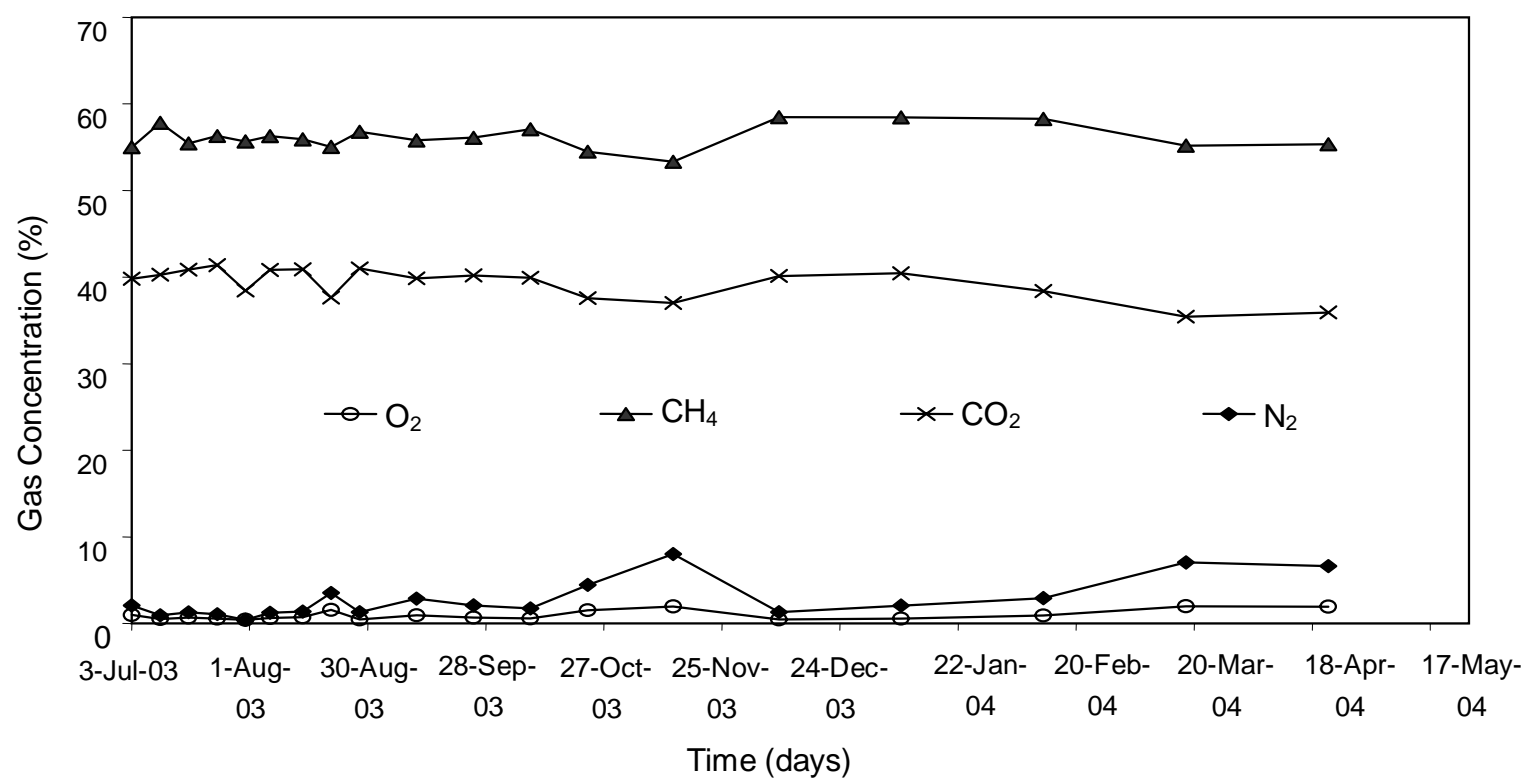

Figure 1. Results from sampling of average gas concentration at Brady road landfill.

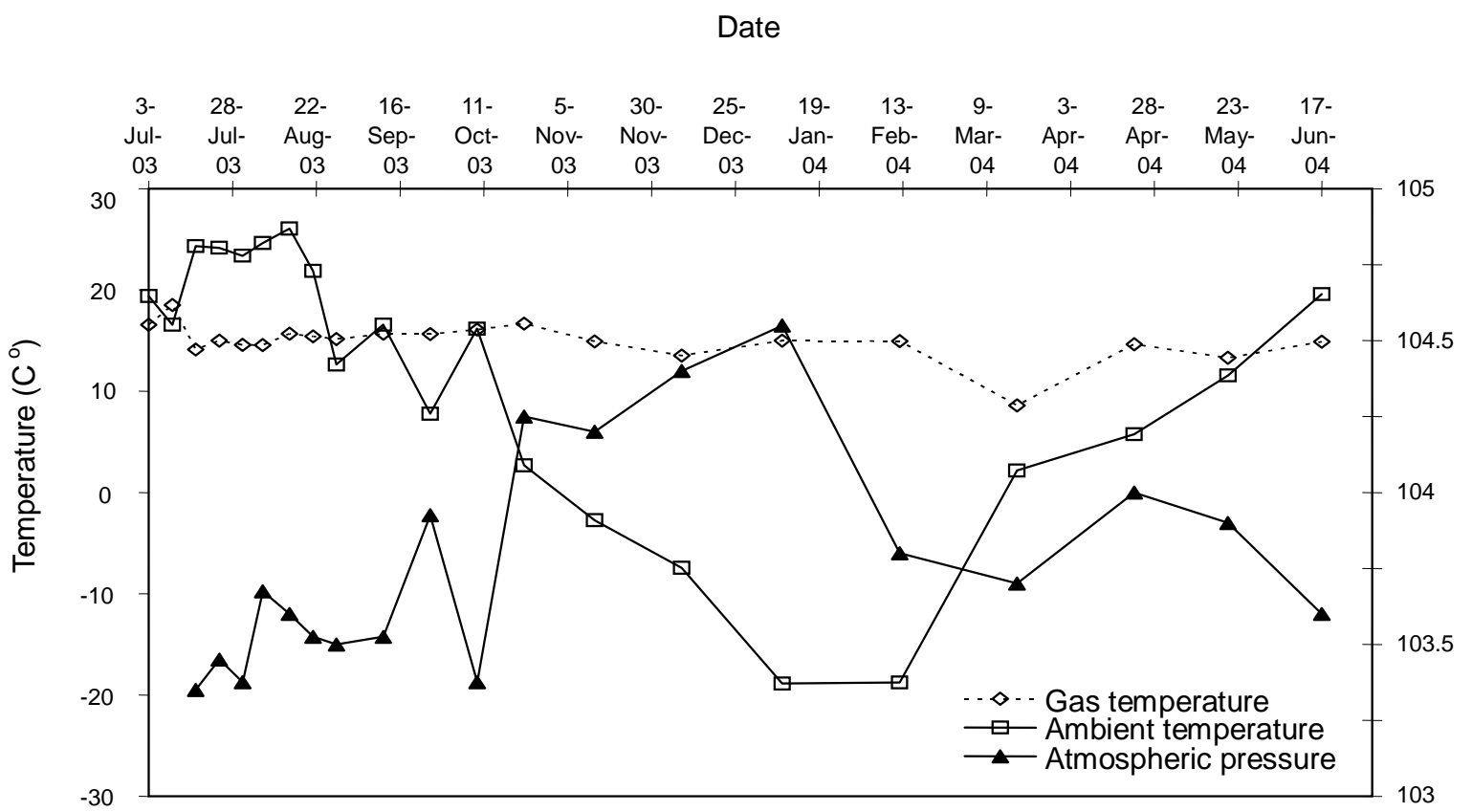

Figure 2. Seasonal changes in atmospheric pressure and temperature as compared to landfill gas temperature. 


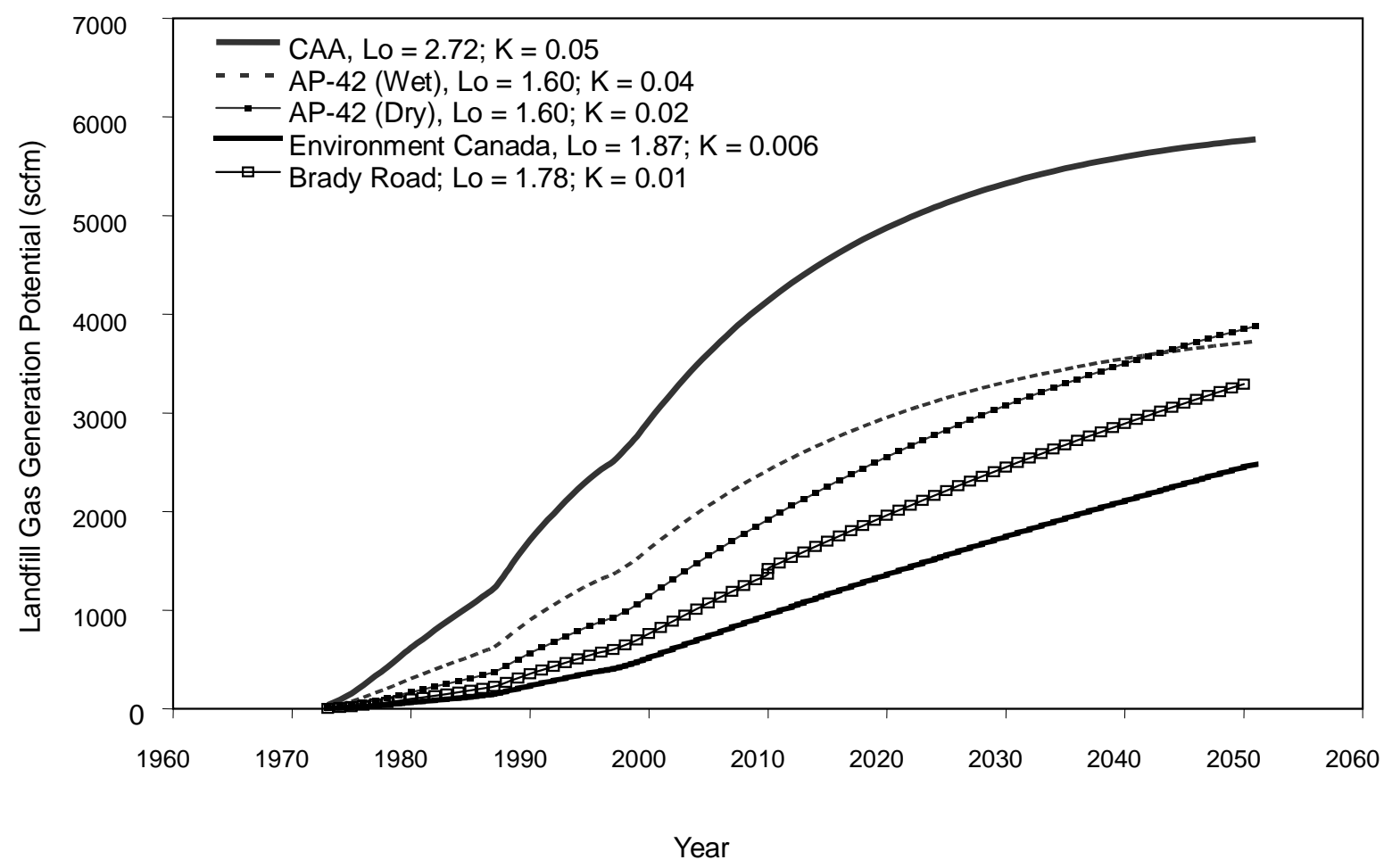

Figure 3. Estimated landfill gas generation potential at the Brady Road Landfill.

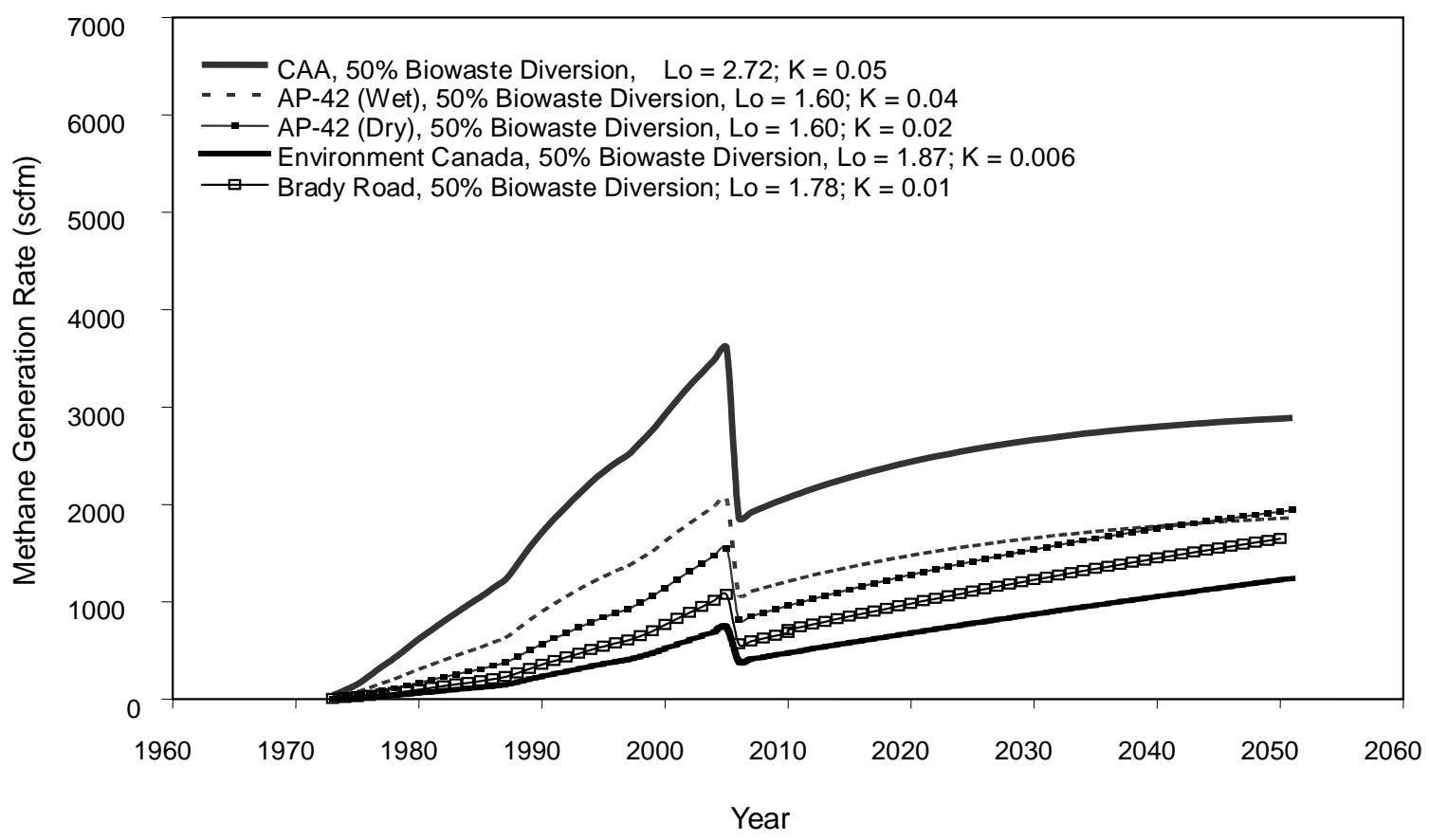

Figure 4. Estimated landfill gas generation potential with 50 percent waste diversion. 


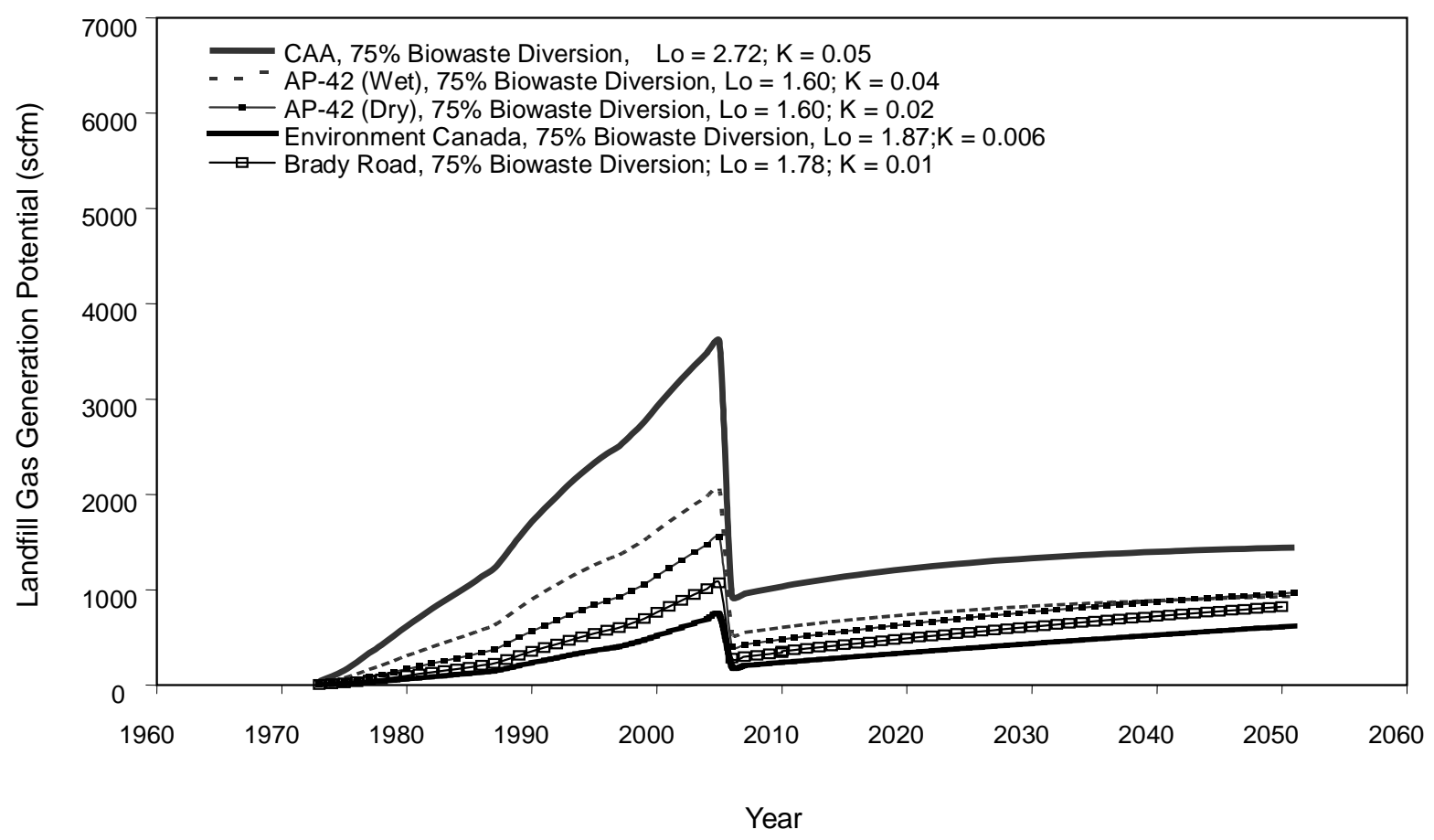

Figure 5. Estimated landfill gas generation potential with 75 percent waste diversion.

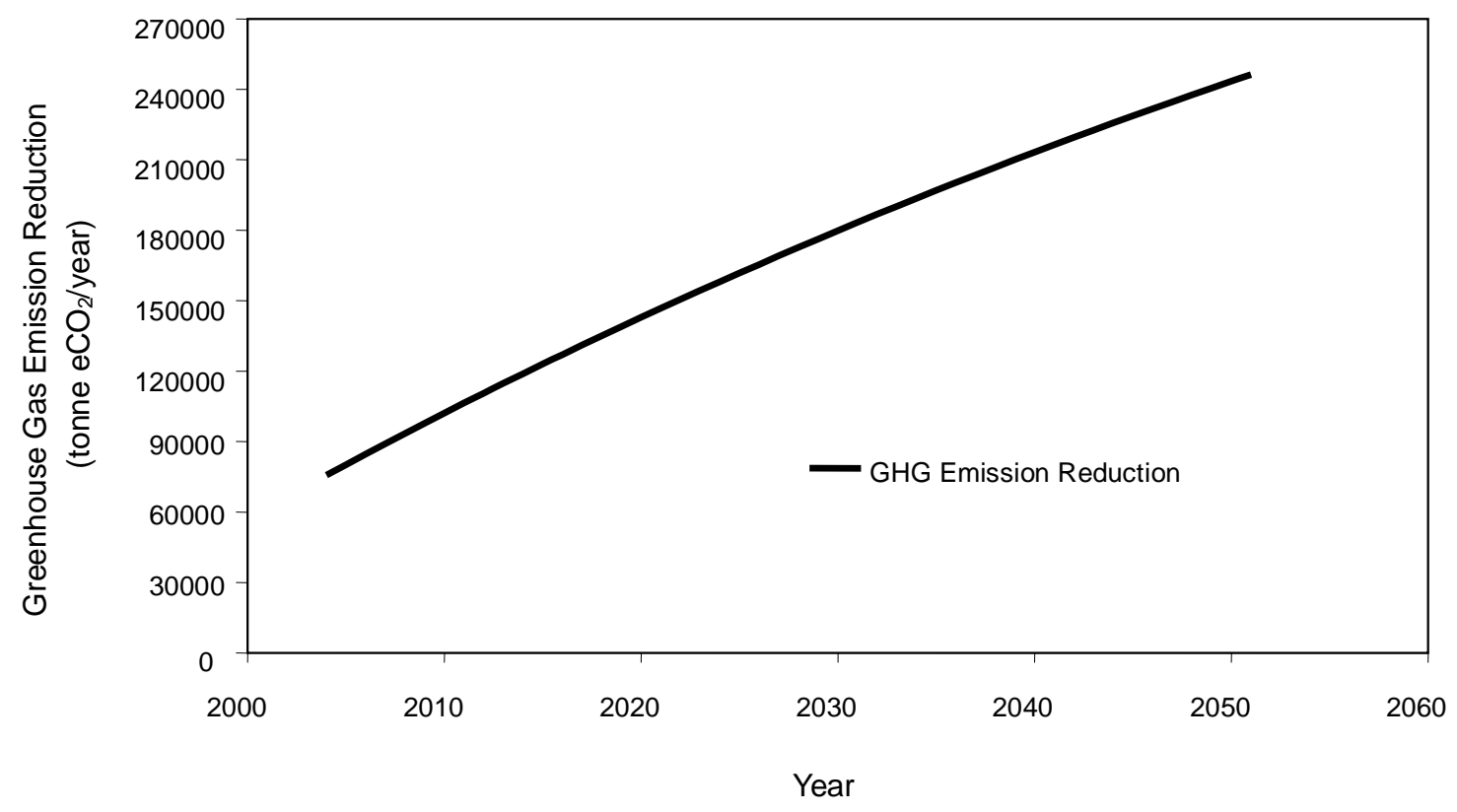

Figure 6. Estimated greenhouse gas emission reduction at Brady road landfill (2004-2050). 


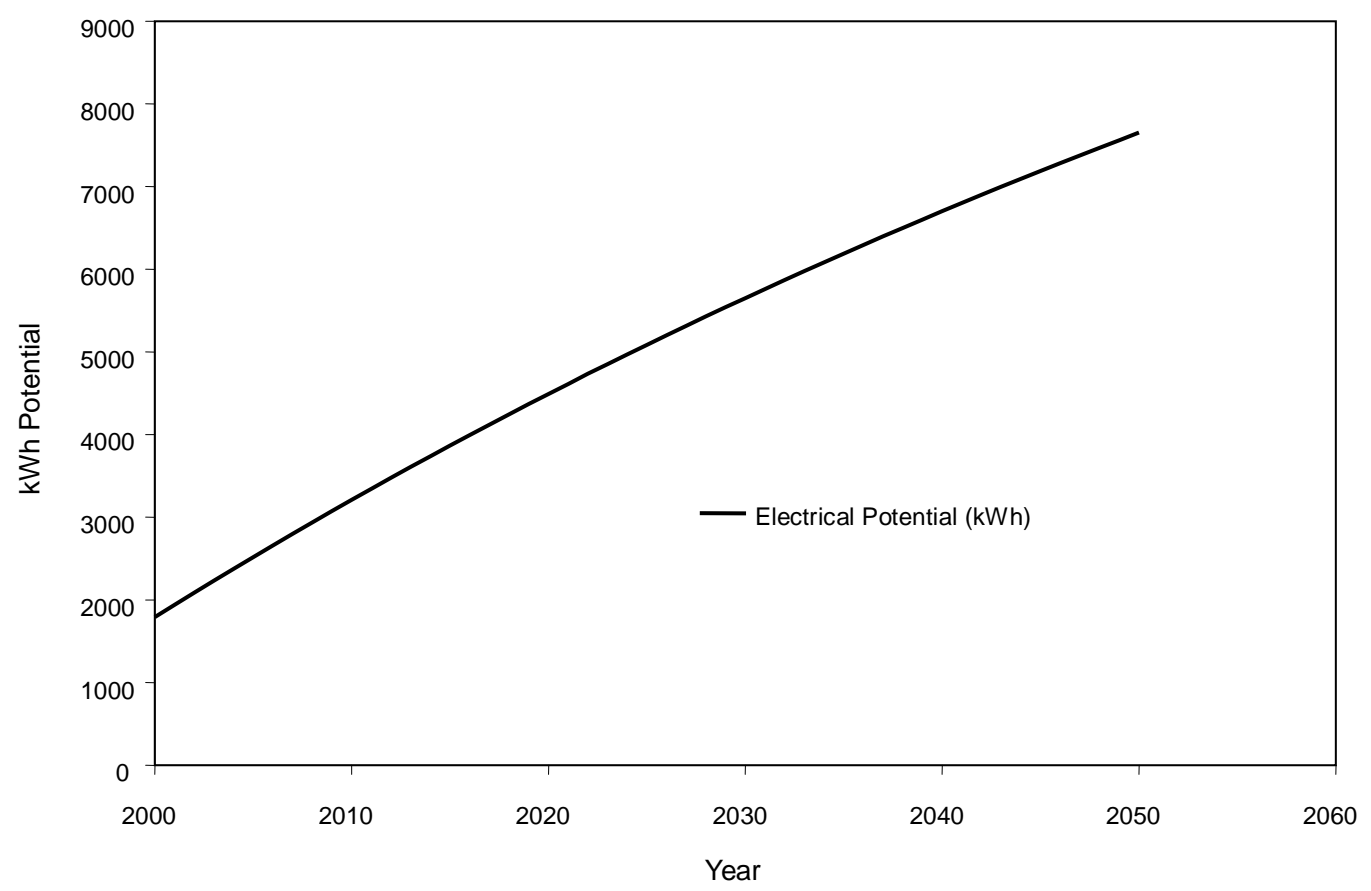

Figure 7. Electricity generation potential at Brady landfill.

age of methane present. To estimate the amount of electricity potential, a collection efficiency of 80 percent is assumed at a site specific heating value of $560 \mathrm{BTU} / \mathrm{ft}^{3}$ based on the percentage of methane present. Figure 7 demonstrates the estimated electrical potential generation at Brady Road Landfill.

Figure 7 provides estimates of electricity generation potential to 2050 to show the growth over time, although Brady Road Landfill has an even longer active lifespan of over a century. In 2050, it is estimated that the electrical potential will be $7742 \mathrm{kWh}$ or $7.7 \mathrm{MWh}$ per year, providing a significant power generation opportunity at Brady Road Landfill.

\section{Discussions}

Findings of landfill gas methane volume (56.10 $\pm 2.56 \%$ by volume) at Brady Road Landfill indicates it is a medium quality gas, with an estimated energy value of about 560 British thermal unit (BTU) per standard cubic foot (scf). The findings of high and stable concentrations of methane and $\mathrm{CO}_{2}$ at Brady Road Landfill reflect the decomposition stage of the waste, at the sampling locations. The waste at the sampling location was two years old and in its stable fermentation stage of anaerobic decomposition. This productive fermentation stage occurs over the initial five to 10 years of waste decomposition, depending on the landfill size and environ- ment and may overestimate concentrations of methane being generated from Brady Road Landfill in older areas.

Landfill gas generation rates could be as high, in 2050, as 5800 SCFM according to Figure 3, or as low as 1200 SCFM as shown in Figure 5. Figure 5 shows that composting programs would result in a dramatic decrease in methane, to as much as one-quarter the business-as-usual rate. Although composting programs usually result in $30-35 \%$ diversion, curbside-pickup of organic waste in combination with pay per bag garbage collection or banning organic wastes and recyclables in garbage collection could easily divert $50 \%$ and $75 \%$ of waste from landfills, as occurred in Halifax (68\% diversion rates in 2003).

The site specific methane generation potential $\left(L_{0}\right)$ of 111 $\pm 2.65 \mathrm{~m}^{3} \mathrm{CH}_{4} /$ tonne of waste or $1.78 \pm 0.0465 \mathrm{~m}^{3} \mathrm{CH}_{4} /$ tonne of waste is obtained from measurements at Brady Road Landfill. This value is closest to that recommended by Environment Canada (117 $\mathrm{m}^{3} \mathrm{CH}_{4} /$ tonne of waste), while it is significantly different from the US EPA value $\left(170 \mathrm{~m}^{3} \mathrm{CH}_{4} /\right.$ tonne of waste). The differences between the site-specific methane generation potential $\left(L_{0}\right)$ and the accepted constants of the US EPA may be as a result of the different make-up of municipal solid waste such as household and commercial waste. These differences can play an important role in the resulting emissions estimate, as each waste stream may have a different degradable organic carbon $(D O C)$ content and thus a different methane generation potential. 


\section{Conclusions}

The Scholl Canyon model is able to estimate greenhouse gas emissions and methane recovery potential for different waste management options. The Scholl Canyon model provides practical information for management decision-making that can provide estimates for potential annual revenue when converted to $\mathrm{kWh}$ potential or BTU. According to this model, recovering methane would create a sustainable renewable source of energy under any of the three scenarios - at $75 \%$ diversion, $50 \%$ diversion or business-as-usual. The energy potential at Brady Road Landfill under any of the waste management scenarios is enormous, according to the model, whether using site-specific constants, generated from monitoring data, or inputting accepted constants. The Brady Road Landfill appears to be capable of generating sufficient amounts of landfill gas emissions to warrant a landfill gas recovery project and a progressive composting program. Curbside-pickup of organic waste in combination with pay per bag garbage collection or banning organic wastes and recyclables are recommended to achieve $50 \%$ and $75 \%$ diversion of waste from landfills, as occurred in Halifax. While each citizen is encouraged to compost, if possible, and limit waste and greenhouse gas generating activities, the City of Winnipeg is providing leadership by undertaking a number of feasibility studies for recovering methane (Tanapat and Thompson, 2004).

When compared to other similar landfills, such as Keele Street Valley Landfill in Toronto, which is currently profitable at recovering methane that contains $47 \% \mathrm{CH}_{4}$ with a landfill capacity of 25 million tonnes, Brady Road Landfill has even more promise. It generates landfill gas with higher methane potential at $56 \%$ and has a higher site capacity (50 million tonnes). Since refuse placement is expected to continue for a century, the landfill gas generation rate will continue to increase far beyond the year 2050 that the Figures 3 to 5 illustrate. Most big landfills have either methane recovery or composting in place, or both, in the case of Edmonton. To maximize resource recovery, the combined approach of municipal composting and energy generation is shown to be possible from this study to turn Brady Road Landfill's waste into an energy goldmine.

Methane recovery of landfill gas represents one of the most cost effective means to reduce greenhouse gas emissions due to both fuel sales and credits from greenhouse gas reduction. With greenhouse gas credits estimated to be at its optimum emission reduction credit of $\$ 2.00$ per tonne of $\mathrm{eCO}_{2}$ reduced an annual revenue $\left(167,489\right.$ tonnes of $\mathrm{eCO}_{2}$ reduced $\times \$ 2$ ) of $\$ 334,978$ per year would result. This amount would offset the cost of operating landfill's gas control system. As well, even at the low scenario for production of 2,000 SCFM the annual revenue for heating fuel is expected to be over one million dollars in 2001 Canadian dollars (Manitoba Hydro, 2003). The electrical potential (average of $5014 \mathrm{kWh} /$ year, 2000 to 2050) indicates that Brady Road Landfill is capable of powering either an internal combustion engine or a gas turbine, as its electrical generation surpasses the engine require- ment (3000 kWh) of these technologies in 2010. Enough energy exists today to power a microturbine as they can be powered at $1 \mathrm{kWh}$ or lower.

The findings of stable concentrations of methane demonstrate that methane generation is not impacted, or impacted minimally, by Winnipeg's extreme climate, which has temperatures dipping below 30 degrees in the winter. As the waste is covered in large cells ten metres deep, anaerobic activity generates heat underground without significant impact by outside temperatures. This finding may warrant higher levels of constants for the decay rate constant accepted by Environment Canada (Llevelton, 1991).

Acknowledgments. This research program was generously supported by Manitoba Hydro and by the inkind support of the City of Winnipeg. Special thanks to the thoughtful comments of the reviewers which significantly improved this paper.

\section{References}

Canadian Electricity Association (CEA) (2002). Joint Study to Reduce GHG Emissions at City Landfills, CEA, Ottawa.

Castro-Wunsch, K. and Ng-Grondin, C. (2001). Greenhouse Gas Emission Reduction through Composting. http://www.cleanitgr eenit.net/pdfs/greenhouse(cas).html.

Conestoga Rovers and Associates (1999). Identification of Potential Landfill Sites for Additional Gas Recovery and Utilization in Canada, Ottawa.

Earthbound Environmental Inc. (2000). City of Winnipeg Waste Composition Study 2000, Winnipeg, Earthbound Environmental Inc..

Environment Canada (1991). Inventory of Methane Emissions from Landfills in Canada. http://www.ec.gc.ca/pdb/ghg/lfg_protocol _e.cfm.

Environment Canada (1999). Identification of Potential Landfill Sites for Additional Gas Recovery and Utilization in Canada, Prepared by Conestoga-Rovers \& Associates.

Environment Canada (2001). Inventory of Landfill Gas Recovery and Utilization in Canada. http://www.ec.gc.ca/nopp/lfg/en/list.cfm.

Gardner, N., Manley, B. and Pearson, J. (1993). Gas Emission from Landfills and their Contributions to Global Warming. Appl. Energy, 44,165-174.

IPCC (Intergovernmental Panel on Climate Change) (1996). Guideline for National Greenhouse Gas Inventories: Reference Manual. http://www.ipcc-nggip.iges.or.jp/public/gp/bgp/5_1_CH4_ Solid_Waste.pdf.

Llevelton, B. (1991). Inventory of Methane Emissions from Landfills in Canada, Environment Canada, Ottawa.

Manitoba Hydro (2003). Energy Matters Insights News Releases Electrical Links. http://www.hydro.mb.ca/news/energy_matters.

shtml.

Manitoba Government (2003). Policy and Actions of the Province of Manitoba on Climate Change. http://www.climatechangeconnec tion.org/pdfs_ccc/govMBpolicy.pdf.

Neitzert, F. (1999). Canada's Greenhouse Gas Inventory: 1997 Emissions and Removals with Trends, Environment Canada, Ottawa.

Pacey, J. (1986). Factors influencing landfill gas production, Proc. of Joint UK/US Engineering Conference, Solihull, 28-31 October, pp. 51-59.

Pembina Institute (2003). LFG Waste-to-Energy Tool. http://www.cli matechangesolutions.com/english/municipal/tools/waste/lfg3.

Province of Manitoba Climate Change Action Plan (2002). Kyoto and Beyond: A Plan of Action to Meet and Exceed Manitoba's Kyoto 
targets, pp. 11.

Smith, A., Brown, K., Ogilvie, S., Rushton, K. and Bates, J. (2001). Waste Management Options and Climate Change, Final Report to the European Commission, AEA Technology Environment, Amsterdam.

Schumacher, M.M. (1983). Landfill Methane Recovery, Park Ridge, Noyes Data Corporation, NJ.

Tanapat, S. and Thompson, S. (2003). Biochemical methane potential of municipal solid waste in Winnipeg landfill, SWANA proceedings, Tampa Bay, FL.

Tanapat, S., Thompson, S., Corman, C. and Kulak, T. (2003). Waste Management Options to Curb Climate Change: Greenhouse Gas Emissions at Brady Road Landfill in Canada, Poster for Air \& Waste Management Association.

Tanapat, S. and Thompson, S. (2004). Applying a Waste Management Model to Analyze Options for Greenhouse Gases at a Specific Landfill: Feasibility of Methane Recovery at Brady Road Landfill, proc. of Journal of Solid Waste Technological Management
Conference.

Tchobanoglous, G., Theisen, H. and Vigil, S. (1993) Integrated Solid Waste Management, McGraw-Hill, NY.

Thompson, S. and Tanapat, S. (2004). A model to determine landfill gas generation for two waste management options, in Air Quality, Global Climate Change, Renewable Energy, $7^{\text {th }}$ Electric Utilities Environmental Conference Proceedings, Tucson, Arizona. www.euce.com.

United States Environmental Protection Agency (1996). Turning a Liability into an Asset: A Landfill Gas-to-Energy Project Development Handbook, EPA, Washington.

United States Environmental Protection Agency (US EPA) (2001). US EPA's Landfill Methane Outreach Program. http://www.epa. gov/lmop.

United States Environmental Protection Agency (2003). Technology Transfer Network. http://www.epa.gov/ttn/catc/products.html\# software. 